\title{
Application of Alternate Healthy Eating Index to Assess Diet Quality in Male Workers
}

\author{
Pramita Ariawati Putri $^{1 *}$, Dodik Briawan ${ }^{1}$, Ikeu Ekayanti ${ }^{1}$ \\ ${ }^{1}$ Department of Community Nutrition, Faculty of Human Ecology, Bogor Agricultural University, \\ Bogor 16680, Indonesia
}

\begin{abstract}
This study aimed to analyze diet quality of male workers. Study design was cross-sectional, involving 101 male workers of PT. Semen Indonesia Tuban, East Java aged 25-55 years old. Subjects were chosen using purposive sampling based on inclusion criterias. US adapted Alternate Healthy Index (AHEI) was used to assess diet quality that consists of 11 components. Components and portions were modified based on Indonesian Dietary Guidelines 2014. The result showed that grains and alcohol components had good score (10) and the lowest score was in sweetened beverages component (1.4). AHEI-score range from 45.1 to 95.7 and the mean was 69.5 . More than half of workers $(75.2 \%)$ diet quality was in need of improvement category (AHEI scores $<76.2$ ). Education level and working unit were correlated with diet quality $(\mathrm{p}<0.05)$. Workers diet quality in PT. Semen Indonesia Tuban needs to be improved.
\end{abstract}

Keywords: alternate healthy eating index, diet quality, male workers

\section{INTRODUCTION}

Globalization encourages nutrition transition around the world, including Indonesia. Consumption of low fat and high fiber diet converted into high fat, high sugar and low fiber (Popkin 2006). Changes in dietary pattern has resulted in increasing obesity problem. Obesity prevalence of adult in Indonesia according to the result of Basic Health Research (Riskesdas) in 2013 is quite high, at $29.8 \%$ (Indonesia Ministry of Health 2014b). Obesity is one of the risk factors for non-communicable disease (NCD) such as type 2 diabetes mellitus, cardiovascular disease, and cancer. NCD contributed to more than half of the mortalitiy rate in Indonesia (Kemenkes RI 2014b). Food consumption is an important factor in preventing NCD. Unfortunately, consumption of food which is good for health such as vegetables and fruits in Indonesia were still low. In contrast, consumption of foods and beverages which are high in sugar, salt, and fat were quite high (Kemenkes RI 2014b). Kemenkes RI in 2014 established the Indonesian Dietary Guidelines (Pedoman Gizi Seimbang 2014), which is expected to be used as a guideline for healthy diet and also to maintain a normal weight for Indonesian population (Kemenkes RI 2014b).

Diet quality is defined as how well food consumption of a person compared to existing recommendations (Alkerwi 2014). Healthy Eating Index (HEI) is an instrument used in the Unit- ed States to assess diet quality. The instrument was arranged based on the Dietary Guidelines for Americans a guidelines for daily dietary intake in United States (Kennedy 1995). Alternate Healthy Eating Index (AHEI) is an instrument modification from HEI in which the index was arranged based on food group and nutrients that poses risk for NCD. Increase in AHEI has a strong association with low risk in the incidence of cardiovasclar disease and type 2 diabetes mellitus (De Koning et al. 2011). Other studies have suggested that AHEI 2010, anothers modification of AHEI which includes omega 3, trans fat, Poly Unsaturated Fatty-Acid (PUFA) component, had shown strong association with risk of NCD such as type 2 diabetes mellitus and coronary heart disease (Chiuve et al. 2012).

Workers spent most of their time in the workplace, which may decrease physical activity that leads to obesity (Rossaa et al. 2012). Basic Health Research in 2010 showed that obesity was more frequent in civil servant/TNI/Police/ employee, and research by Nurjanah and Roosita (2015) showed that central obesity in male workers in cement company was high $(96.1 \%)$. Research by Amrin et al. (2013) showed that food consumption quality in Indonesian adult male was still low. Againts the mentioned back drops, there is a need to asess diet quality of cement company workers in relation to risk of NCDs. AHEI is a tool that provide such way to measure this. However, research to assess diet quality us-

"Corresponding Author: Tel: +6285640860392 email: putriipramita1501@gmail.com. 
ing US adapted AHEI has never been done in Indonesia. Thus, the objective of this study is to analyze diet quality in male workers using AHEI adjusted to Indonesian Dietary Guidelines 2014.

\section{METHODS}

\section{Design, location, and time}

The study design was cross sectional. Research took place in PT. Semen Indonesia Tuban, East Java Province from January-March 2017. Ethical approval was obtained from the Ethic Committee of Health Research, Faculty of Medicine, University of Indonesia No. 1055/UN2.F2/ ETIK/2016.

\section{Sampling}

Subjects in this study were male workers in PT. Semen Indonesia that had their comedical check-up in February-March 2017. The work units included were the production units (production of raw materials, cement, slag I and II, K3) and non-production (communication and public facilities, commercial and financial). Subjects selected purposively to meet sampling quota of 101 male workers included 10\% drop out anticipation used formulation by Ariawan (1998). The inclusion criterias for the subjects were as follow: was aged 25-55 years old, workers at PT. Semen Indonesia in Tuban, not taking any medicine that lowers blood glucose, blood pressure and cholesterol level, not in certain diet and signed the informed consent. Exclusion criteria in this research were subjects' resignation and incomplete data.

\section{Data collection}

Data were obtained through interview between researcher and subjects using structured questionnaire and anthropometry assessment. Data of subjects characteristics are age, education level, working duration in the company, working unit, marital status was obtained through interview using structured questionnaire while nutritional status was gathered using anthropometry assessment (body weight measured using digital scale brand "Cambria" with $0.1 \mathrm{~kg}$ precision and height measurement using microtoise with $0.1 \mathrm{~cm}$ accuracy). Food consumption data were acquired from Semi-Quantitative Food Frequency Questionnaire (SQ-FFQ) for the previous 7 days.

\section{Data analysis}

Data on subject characteristics (age, education level, working duration in the company, working unit, marital status, and nutritional status) was categorized and presented in percentages. Nutritional status determined by body mass index (BMI) and categorized as normal (BMI 18.5-22.9), overweight (BMI 23-24.9), and obese (BMI $\geq 25$ ) (WHO 2000).

Diet quality. Food consumption data were processed to determine the diet quality of subjects based on adapted AHEI that consisted of 11 components developed by Chiuve et al. (2012). AHEI used in this study has been adjusted in components and portions to Indonesian Dietary Guidelines 2014 issued by the Indonesia Ministry of Health. These adjustments were the maximum, minimum and portion criteria for vegetables, fruits, nuts, omega 3 and sodium component, and whole grains component converted into grains. AHEI used in this study had $\alpha$-Cronbach value of 0.61. Maximum score of each component reached was 10 (Table 1).

\section{Tabel 1. Modified AHEI Indonesia}

\begin{tabular}{|c|c|c|}
\hline Component & $\begin{array}{c}\text { Minimum } \\
\text { criteria score } \\
(0)\end{array}$ & $\begin{array}{c}\text { Maximum } \\
\text { criteria score } \\
(10) \\
\end{array}$ \\
\hline Vegetables & 0 portion & 3-4 portions \\
\hline Fruits & 0 portion & $\geq 5$ portions \\
\hline Grains & $0 \mathrm{~g}$ & $75-90 \mathrm{~g}$ \\
\hline $\begin{array}{l}\text { Sweetened } \\
\text { beverages }\end{array}$ & $\geq 1$ portions & 0 portions \\
\hline $\begin{array}{l}\text { Nuts and } \\
\text { legumes }\end{array}$ & 0 portion & $\geq 3$ portions \\
\hline $\mathrm{RPM}$ & $\geq 1,5$ portions & 0 portion \\
\hline Trans-fat & $\geq 4 \%$ energy & $\leq 0.5 \%$ energy \\
\hline Omega 3 & $0 \mathrm{mg}$ & $\geq 160 \mathrm{mg}$ \\
\hline PUFA & $\leq 2 \%$ energy & $\geq 10 \%$ energi \\
\hline Sodium & $>2,000 \mathrm{mg}$ & $\leq 2,000 \mathrm{mg}$ \\
\hline Alcohol & $\geq 2.5$ portions & 0 portion \\
\hline $\begin{array}{l}\text { Total AHEI } \\
\text { score }\end{array}$ & 0 & 110 \\
\hline
\end{tabular}

Components scoring using portions or grams (vegetables, fruits, grains, nuts and legumes, sweetened beverages, red / processed meat (RPM), omega 3, sodium, and alcohol) were calculated by dividing portions or grams consumed in one day with maximum score criteria and multiplied by 10 . While the components that were assessed by percent contribution to total energy intake (trans-fat and PUFA), total energy 
was aqquired from the Indonesian Food Composition List (DKBM) while the nutrient content of foods which were not found in DKBM (omega 3, PUFA, trans-fat and sodium) were obtained from Nutrisurvey, Thailand Food Composition Table (Thai-FCT) (Judprasong et al. 2015) or Australian FCT (AUSNUT 2016). Score of each component was summed to obtain total AHEI score. The total AHEI scores were categorized into two categories according to the highest quartile on the AHEI score of workers (Chiuve et al. 2012). Resulted in the need improvement category cut off in total HEI score of $<76.2$ and good if $\geq 76.2$. Table 1 presents the components, maximum and minimum scores criteria on the modified AHEI. For example, if within one day the worker consumed 2 portions of vegetables, then the calculation of the vegetable component score was 2 divided by 3 (maximum criteria of the vegetable component) and multiplied by 10 . The vegetable component score for the worker is 6.7.

Mean adequacy ratio. Mean Adequacy Ratio (MAR) calculated from the average adequacy level of energy and other nutrients. The maximum nutritional adequacy rate is 100 (Gibson 2005). There are 4 nutrients included in the MAR calculation in this study, ie energy, protein, fat, and carbohydrate.

Data analysis included univariate analysis (descriptive analysis) and bivariate analysis. Bivariate analysis used were chi-square test to see the relationship between the characteristics of the subject and diet quality and pearson correlation test to determine the relationship between the level of adequacy of energy, protein, fat, carbohydrates, MAR and diet quality.

\section{RESULTS AND DISCUSSION}

\section{Subject characteristics}

Subjects were male workers and mostly in the age of $40-55$ years $(79.2 \%)$. The education level was high school and vocational education $(71.3 \%)$, worked in the company for $\geq 10$ years $(90.1 \%)$. Most of the subjects worked in the production unit $(62.4 \%)$, had income $>\mathrm{Rp}$ $10,000,000$ (55.2\%), were married (95.0\%). Most of the subjects were classified as overweight / obese category $(86.1 \%)$.

\section{Diet quality}

Table 2 shows subjects' consumption and HEI score. The total AHEI score of the subjects ranged from 45.1 to 95.7 and the mean AHEI score was 69.5. This score is higher compared to research by Chiuve et al. (2012) which found a mean score of 52.4. Diet quality was classified into two categories, "good" if the score was $\geq 76.2$ and "need improvement" if the score was $<76.2$. There were $75.2 \%$ subjects in "need improvement" diet quality category while only $24.8 \%$ of subjects in "good" category. In agreement with research on Thai workers using the Thailand Healthy Eating Index (THEI) that $69.0 \%$ of subjects had poor dietary quality (Taechangam et al.

Tabel 2. Subjects food consumption and AHEI scores

\begin{tabular}{lcc}
\hline \multicolumn{1}{c}{ Components } & $\begin{array}{c}\text { Subject consumption } \\
\text { Mean } \pm \text { SD (median) }\end{array}$ & $\begin{array}{c}\text { Subject AHEI scores } \\
\text { Mean } \pm \text { SD (median) }\end{array}$ \\
\hline Vegetables (portion) & $0.4 \pm 0.4(0.3)$ & $1.5 \pm 1.3(0.9)$ \\
Fruits (portion) & $1.6 \pm 1.3(1.1)$ & $3.1 \pm 2.5(2.3)$ \\
Grains (g) & $447.5 \pm 221.1(400.0)$ & $10.0(10.0) \pm 0.0$ \\
Sweetened beverages (portion) & $1.4 \pm 0.9(1.0)$ & $1.4 \pm 2.9(0.0)$ \\
Nuts and legumes (portion) & $2.2 \pm 1.9(1.6)$ & $7.3 \pm 6.3(5.2)$ \\
RPM (portion) & $0.4 \pm 0.8(0.3)$ & $8.0 \pm 2.2(8.1)$ \\
Trans-fat (\% energy) & $1.7 \pm 0.9(1.5)$ & $6.7 \pm 2.4(7.1)$ \\
Omega 3 (mg) & $95.2 \pm 80.9(72.4)$ & $5.2 \pm 3.0(4.5)$ \\
PUFA (\% energy) & $5.3 \pm 4.7(4.3)$ & $4.9 \pm 2.6(4.3)$ \\
Sodium (mg) & $885.4 \pm 725.7(446.7)$ & $8.6 \pm 3.5(10.0)$ \\
Alcohol (portion) & $0.0 \pm 0.0(0.0)$ & $10.0 \pm 0.0(10.0)$ \\
Total AHEI score & & $69.5 \pm 10.2(69.4)$ \\
\hline
\end{tabular}


2008). Amrin et al. (2013) showed similar results that adult males in Indonesia had low quality of food consumption compared with the standard Balanced Diet Guideline (PUGS) in 2011 using the data from Basic Health Research in 2010.

Research by Assmann et al. (2014), found that men with lower diet quality was associated with greater 6-year weight gain as compared to the high diet quality group. Someone with low diet quality had higher risk to experience NCD. Research by Akbaraly et al. (2011) in adult age 39-63 in the UK pointed that a person with low diet quality had higher risk of developing coronary heart disease (CHD) compared to those with good diet quality. A cohort study of adult men in the United States showed that good diet quality reduced the risk of developing type 2 diabetes mellitus, but any increase of 1 SD from AHEI score reduced the risk of type 2 diabetes mellitus by $9-13 \%$. (De Koning et al. 2011).

The low diet quality of male workers in this study was due to low consumption of vegetables and high consumption of sweetened beverages shown by low score of 1.5 and 1.4. Consumption of grains and alcohol component of the subject were good, marked by the mean score of that components. The mean score of RPM and sodium were close to a maximum which were 8.0 and 8.6. Components of fruits, nuts, trans-fat, omega-3 and PUFA consumptions need to be increased as the were mean score ranged from 5.2 to 6.8 .

Vegetables. The mean consumption of vegetables in the subjects is low with only 0.4 portions in one day (Table 2). Vegetables consumption of the subject had not fulfilled the recommendation of Indonesian Dietary Guidelines 2014 that is 3-4 portions in one day and relatively low compared to vegetable consumption proportion in Tuban. The typical consumption in Tuban district was equal to 1.5 portion and vegetable consumption in men in East Java Province that was 1.4 (Indonesia Ministry of Health 2014c). The low consumption of vegetables in subjects was suspected because subjects perceived that vegetables are just complementary to the rice and animal protein so that vegetables consumptions are unable to be maximized. Vegetable is rich in vitamins and minerals that have a positive impact on health. Research by Esmaillzadeh et al. (2006) mentioned that high consumption of vegetables can prevent the occurrence of metabolic syndrome.

Fruits. Subjects fruit consumption was 1.6 portionss. Consumption of fruit had not reached the recommendation of Indonesian Dietary Guidelines 2014 which amounted to 5 portions. However, the mean of fruit consumption in this study was higher than the proportion of fruit consumption in Tuban ( 0.6 portions) and the proportion of fruit consumption in males in East Java (0.5 portions) (Kemenkes RI 2014c). Lack of fruit consumption can lead to obesity and PTM such as diabetes, hypertension, and heart and blood vessel disease (Slavin \& Lloyd 2012).

Grains. Foods included in the grain group in this study were rice, brown rice, cereal or oatmeal. Grains is needed by the body because of the high carbohydrate which was served as a source of energy (Kemenkes RI 2014b). Table 2 shows that the mean of grains consumption in subjects was $447.5 \mathrm{~g}$ and met the maximum score criteria. In line with research from Waloya et al. (2013) conducted in the city and district of Bogor that the consumption of grains in men per day was $455.5 \mathrm{~g}$. White rice was the grains consumed by all subjects, while other grains included in this component were very rarely consumed. A switch to healthier grain is suggested to improve diet quality and health Consumption of grains besides white rice such as brown rice, cereal or oatmeal alternately in everyday has shown benefit for the body because it was rich in fiber that helps control blood cholesterol. Complex carbohydrates contained in the food can also prevent high blood glucose because it is more slowly converted into blood sugar (Kemenkes RI 2014b).

Sweetened beverages. The mean consumption of sweetened beverage amongst subjects were 1.4 portions, a very low mean score (1.4) (Table 2). Data from Basic Health Research in 2013 showed that in East Java province where the district of Tuban is located that the proportion of people who consumed beverages with sweetener $\geq 1$ times per day were higher than those who consumed 1-6 times per week or $\leq 3$ times per month (Kemenkes RI 2014c). Sweetened beverages such as tea or coffee added with sugar, other instant beverages are difficult to separate from the food consumption pattern of today's society. Meta-analysis study by Malik et al. (2010) showed that a person who consumed sweetener 1-2 times a day had $26 \%$ higher risk of developing type 2 diabetes mellitus.

Nuts and legumes. According to Indonesian dietary guidelines 2014, good consumption of nuts and legumes defined as 3-4 portions/day. Table 2 shows that the mean consumption of nuts and legumes on the subject was 2,2 portions and had not reached the recommendation of Indone- 
sian dietary guidelines 2014. Nuts and legumes also processed to be tofu and tempeh which are sources for plant based protein. In addition nuts contain potassium that can lower high blood pressure. Nuts also contain antioxidants and have no cholesterol content. Consumption of tempeh and soybean can increase insulin sensitivity and lower blood sugar level (Kemenkes RI 2014b). Systematic review conducted by Demersay et al. (2017) highlighted that the intake of vegetable protein has an inverse relationship with both systolic and diastolic blood pressures. Other studies suggested that increased intake of vegetable protein was not associated with increased risk of type 2 diabetes mellitus (Van-Nielen et al. 2014).

$\boldsymbol{R} \boldsymbol{P M}$. Food included in RPM was red meat such as beef and mutton and processed meat such as meatball, corned beef, and sausage which are sources of animal protein for the body. The mean consumption of RPM in this study was 0.6 portions, which was higher than the maximum $(0$ portion) score criteria. In line with the research from Waloya et al. (2013) conducted in Bogor that male meat consumption was $23.13 \mathrm{~g}$ or 0.67 portions of beef. Animal protein has advantages over plant based protein due to more complete amino acids and better nutrient quality because they are more readily absorbed by the body. On the flip side, red meat has higher cholesterol and saturated fat content thus the consumption needs to be limited in adult (Indonesia Ministry of Health 2014b). The consumption of animal protein belonging to the RPM group can be replaced by animal protein present in low-fat groups such as fish or poultry. RPM consumption associated with higher risk of metabolic syndrome, compared to other animal protein consumption (Becerra et al. 2016).

Trans-fat. Table 2 shows that mean contribution of trans-fats to energy is $1.7 \%$, which means that it had not met the maximum score criteria ( $\leq 0.5 \%$ of the total energy intake). The high mean consumption of trans-fat can be caused by frying cooking process of daily food such as fried chicken, fried tempeh and bakwan (vegetables fritters). Trans-fat is the result of hydrogenation of unsaturated fatty acids. Unsaturated fatty acids possess highly heat-sensitive properties, deepfrying can form long-chain saturated fatty acids and trans fatty acids. Hydrogenation in commercial products has a purpose to reduce the rate of oxidation reaction so that the resulting product is denser, more durable and stable in the presence of oxidation. Trans-fat consumption has nega- tive impact on the body because it can increase LDL cholesterol and lowering HDL cholesterol (Sartika 2008). Trans-fat consumption should be limited because it is associated with insulin resistance and metabolic syndrome, $2 \%$ of trans-fat consumption from total energy intake associated with increased incidence of CHD (Micha \& Mozaffarian 2009).

Omega 3. The mean omega 3 consumption were $95.2 \mathrm{mg}$ (Table 2) and had not reached the maximum score which is $>160 \mathrm{mg}$. The low consumption of omega 3 was thought to be due to a lack of consumption of omega 3 sources such as fish, fish oil and nuts. Omega 3 is one type of unsaturated fatty acids with double bonds that is important for immune system as well as heart and blood vessels (Oken \& Belfort 2010). Another study by Wallin et al. (2017) stated that fish consumption of more than 3 times/week lowered the risk of myocardial infarction compared to consumption less than 3 times/month.

$\boldsymbol{P U F A}$. PUFA is fatty acids that have two or more double bonds. PUFA is mostly found in fish and vegetable oils also in nuts and seeds such as omega 3 and omega 6. Mean percentage of PUFA contribution amongst subject had not fulfilled the maximum criteria $(\geq 10 \%$ total energy) (Table 2). PUFA consumption was not maximized because of the consumption of nuts and consumption of omega 3 sources were also not maximal. PUFAs (arachidonic fatty acids, linoleic and linolenic acids) have good benefits for the body because they function in fat transport and metabolism such as clearing plasma from VLDL and decreasing triglyceride production in the liver (Sartika 2008).

Sodium. Mean intake of Sodium in subjects was $885.4 \mathrm{mg}$ indicating that sodium consumption in subjects had met the criteria for obtaining maximum score (Table 2). Mean of sodium consumption was able to meet the maximum criteria because the subjects in this study did not consume much packaged foods high in Sodium such as instant noodles and rarely ate fast food. That result in line with the proportion of people in Tuban who consume savory taste foods $>1$ time in one day which is only $19.3 \%$ and people who consume savory foods 1-6 times a week was more frequent (56.2\%) (Indonesia Ministry of Health 2014c). High sodium intake was associated with increased blood pressure and the incidence of hypertension (Takase et al. 2015). Other studies stated that limiting sodium consumption was associated with a decrease in 
blood pressure and had an inverse relationship with the occurrence of metabolic syndrome (Sarno et al. 2009).

Alcohol. None of subjects consumed alcohol either in the form of beverages or in food, this may be due to a largely religious factor that did not permitted alcohol consumption. Based on these results, the entire subject can reach the maximum criteria in the components of alcohol (Table 2). Alcohol consumption may posed negative impact on the body, research by Baik and Shin (2008) suggested frequent consumption of alcohol had strong relationship with the incidence of metabolic syndrome.

\section{Association between MAR and diet quality}

There was an association between adequacy level of energy, protein, fat and MAR and diet quality $(\mathrm{r}=0.3-0.5 ; \mathrm{p}<0.01)$ and there was association between carbohydrate adequacy level and diet quality $(\mathrm{r}=0.022 ; \mathrm{p}<0.05)$. MAR can be used as a gold-standard to determine the diet quality of food consumption (Amrin et al. 2013; Perdana et al. 2014). Significant association between MAR and diet quality suggests that diet quality obtained from AHEI may reflects the nutritional quality of food consumption of the workers.

\section{Association between subjects characteristics and diet quality}

There was no association between age, duration of work, income, marital status and nutritional status with diet quality $(\mathrm{p}>0.05)$. Workers with high school and vocational education were significantly associated with $73.8 \%$ decrease risk in diet quality "need improvement" category than workers with recent college education $(\mathrm{OR}=0.262 ; 95 \% \mathrm{CI}: 0.07-0.95)$. Based on research conducted in Ireland, most of the workers who have higher education levels were not accompanied by good nutritional knowledge. Thus nutrition knowledge explained the better diet rather than the educational level (Geaney et al. 2015)

Workers in production unit were significantly associated with $67.7 \%$ risk reduction in diet quality as classified in "need improvement" category than workers in non-production units $(\mathrm{OR}=0.323$; 95\%CI:0.11-0.95). Workers in production unit only consume food at break time, in contrast to workers in non-production units who are allowed to eat or drink while working. Frequent consumption of snack foods with high trans-fat content or consumption of sweetened beverages contributed to the lowering of the diet quality in workers. This result is in line with Croce et al. (2007) that diet quality in workers in production unit was better than in non-production unit.

\section{CONCLUSION}

A third of male workers had diet quality in the category of need improvement. The low diet quality was due to very low vegetable consumption and high consumption of sweetened beverages. The consumption of grains and alcohol in male workers were good. Consumption of sodium, RPM, and trans-fat needs to be limited, while consumption of fruits, nuts, omega 3 , and PUFA should be increased. There was an association between educational level and work unit with diet quality.

Food management in accordance with the Indonesia Dietary Guidelines 2014 can be done by companies to improve the diet quality of workers either for workers in production unit or non-production unit. Nutritional knowledge variables can be added in subsequent research. Cutoff point development in categorizing diet quality in Indonesia also needs to be done in future research.

\section{REFERENCES}

Alkerwi A. 2014. Diet quality concept. Nutrition 30(6):613-618.

Akbaraly TN, Ferrie JE, Berr C, Brunner EJ, Head J, Marmot MG, Singh-Manoux A, Ritchie K, Shipley MJ, Kivimaki M. 2011. Alternative Healthy Eating Index and mortality over 18 y of follow-up: Results from the Whitehall II cohort. Am J Clin Nutr 94(1):247-253.

Amrin AP, Hardinsyah, Cesilia MD. 2013. Alternatif indeks gizi seimbang untuk penilaian mutu gizi konsumsi pangan pria dewasa Indonesia. J Gizi Pangan 8(3):167-174.

Ariawan I. 1998. Besar dan Metode Sampel pada Penelitian Kesehatan. Jakarta: Universitas Indonesia.

[AUSNUT] Australian Food, Supplement and Nutrient Database 2011-2013. 2016. Australia: Food Standards Australia New Zealand.

Assmann KE, Lassale C, Galan P, Hercberg S, Kesse-Guyot E. 2014. Dietary quality and 
6-year anthropometric changes in a sample of French middle-aged overweight and obese adults. Plos One 9(2):87083.

Baik I, Shin C. 2008. Prospective study of alcohol consumption and metabolic syndrome. Am J Clin Nutr 87(5):1455-63.

Becerra TN, Babio N, Martínez GMÁ, Corella D, Estruch R, Ros E, Fitó M, Serra Majem L, Salaverria I, Lamuela RMR, Lapetra J, Gómez EG, Fiol M, Toledo E, Sorlí JV, Pedret LMR, Salas-Salvadó J. 2016. Replacing red meat and processed red meat for white meat, fish, legumes or eggs is associated with lower risk of incidence of metabolic syndrome. Clin Nutr 35(6):14421449.

Chiuve SE, Fung TT, Rimm EB, Hu FB, McCullough ML, Wang M, Stampfer MJ, Willett WC. 2012. Alternative dietary indices both strongly predict risk of chronic disease. J Nutr 142(6):1009-1018.

Croce N, Bracci M, Ceccarelli G, Barbadoro P, Prospero E, Santarellia L. 2007. Body mass index in shift workers: relation to diet and physical activity. G Ital Med Lav Ergon 29(3 Suppl):488-489.

De Koning L, Chiuve SE, Fung TT, Willett WC, Rimm EB, Hu FB. 2011. Diet quality scores and the risk of type 2 diabetes in men. Diabetes Care 34(5):1150-1156.

Demersay TC, Marniche DA, Arfsten J, Egli L, Gaudichon C, Karagounis LG, Tome D. 2017. A systematic review of the effects of plant compared with animal protein sources on features of metabolic syndrome. $\mathrm{J}$ Nutr 147(3):281-292.

Esmaillzadeh A, Kimiager M, Mehrabi Y, Azadbakht L, Hu FB, Willet WC. 2006. Fruit and vegetable intakes, C-reactive protein, and the metabolic syndrome. Am J Clin Nutr 84(6):1489-1497.

Geaney F, Fitzgerald S, Harrington JM, Kelly C, Greiner BA, Perry IJ. 2015. Nutrition knowledge, diet quality and hypertension in a working population. Prev Med Rep 2(1):105-113.

Gibson RS. 2005. Principles of Nutritional Assessment 2nd ed. Oxford University Press, New York.

Judprasong K, Puwastien P, Nitithamyong A, Sridonpai P, Somjai A. 2015. Institute of Nutrition, Mahidol University. Thai Food Composition Database. http://www.inmu. mahidol.ac.th/thaifcd
[Kemenkes RI] Kementrian Kesehatan Republik Indonesia. 2010. Laporan Riset Kesehatan Dasar Tahun 2010. Jakarta: Kemenkes RI.

[Kemenkes RI] Kementrian Kesehatan Republik Indonesia. 2014a. Laporan Riset Kesehatan Dasar 2013. Jakarta: Kemenkes RI.

[Kemenkes RI] Kementrian Kesehatan Republik Indonesia. 2014b. Pedoman Gizi Seimbang. Jakarta: Kemenkes RI.

[Kemenkes RI] Kementrian Kesehatan Republik Indonesia. 2014c. Riskesdas dalam Angka Provinsi Jawa Timur 2013. Jakarta: Kemenkes RI.

Kennedy ET, Ohls J, Carlson S, Fleming K. 1995. The Healthy Eating Index: design and applications. J Am Diet Assoc 95(10):11031108.

Malik VS, Popkin BM, Bray GA, Després JP, Willett WC, Hu FB. 2010. Sugar-sweetened beverages and risk of metabolic syndrome and type 2 diabetes a meta-analysis. Diabetes Care 33(11):2477-2483.

Micha R, Mozaffarian D. 2009. Trans fatty acids: effects on metabolic syndrome, heart disease and diabetes. Nat Rev Endocrinol 5(6):335-344.

Nurjanah F, Roosita K. 2015. Gaya hidup dan kejadian sindrom metabolik pada karyawan laki-laki berstatus gizi obes di PT. Indocement Citeureup. J Gizi Pangan 10(1):1724.

Oken E, Belfort MB. 2010. Fish, fish oil, and pregnancy. JAMA 304(15):1717-1718.

Perdana SM, Hardinsyah, Damayanthi E. 2014. Alternatif indeks gizi seimbang untuk penilaian mutu gizi konsumsi pangan wanita dewasa Indonesia. J Gizi Pangan 9(1):4350.

Popkin BM. 2006. Global nutrition dynamics: the world is shifting rapidly toward a diet linked with noncommunicable diseases. Am J Clin Nutr 84(2):289-98.

Rossaa CEB, Caramoria PRA, Manfroia WC. 2012. Metabolic syndrome in workers in a university hospital. Rev Port Cardiol 31(10):629-636.

Sarno F, Jaime PC, Ferreira SRG, Monteiro CA. 2009. Sodium intake and metabolic syndrome : a systematic review. Arq Bras Endocrinol Metabol 53(5): 608-616.

Sartika RAD. 2008. Pengaruh asam lemak jenuh, tidak jenuh dan asam lemak trans terhadap kesehatan. KESMAS 2(4):154-160.

Slavin JL, Lloyd B. 2012. Health benefits of fruits and vegetables. Adv Nutr 3(4):506-516. 
Taechangam S, Pinitchun U, Pachotikarn C. 2008. Development of nutrition education tool: healthy eating index in Thailand. Asia Pac J Clin Nutr 17(1):365-367.

Takase H, Sugiura T, Kimura G, Ohte N, Dohi Y. 2015. Dietary sodium consumption predicts future blood pressure and incident hypertension in the Japanese normotensive general population. JAHA 4(8):1-7.

Van-Nielen M, Feskens EJ, Mensink M, Sluijs I, Molina E, Amiano P, Ardanaz E, Balkau B, Beulens JW, Boeing H. 2014. Dietary protein intake and incidence of type 2 diabetes in Europe: the EPIC InterAct CaseCohort Study. Diabetes Care 37(7):18541862.
Wallin A, Orsini N, Forouhi NG, Wolk A. 2017. Fish consumption in relation to myocardial infarction, stroke and mortality among women and men with type 2 diabetes: A prospective cohort study. Clin Nutr 12(1):1-7.

Waloya T, Rimbawan, Andarwulan N. 2013. Hubungan antara konsumsi pangan dan aktivitas fisik dengan kadar kolesterol darah pria dan wanita dewasa di Bogor. J Gizi Pangan 8(1): 9-16.

[WHO] World Health Organization. 2000. WHO/ IOASO/IOTF: The Asia Pasific perspective: Redefining Obesity and Its Treatment. Australia: Health Communnication Australia. 